\title{
Assessing the awareness of solar lighting gadgets among rural people of Uttarakhand
}

\section{Janki Joshi and Promila Sharma}

Received: 08.05.2019; Revised: 07.10.2019; Accepted: 21.10 .2019

See end of the paper for authors' affiliations

\section{Janki Joshi}

Department of Family Resource Management, College of Home Science, G.B. Pant University of Agriculture and Technology,

Pantnagar, U.S. Nagar

(Uttarakhand) India

Email : janki.30121@gmail.com
ABSTRACT : Close to 70 per cent of India's population lives in villages. Even today, 80,000 villages in India have never been electrified. Even the electrified villages suffer from scanty power supply. This situation exist more in hill areas where there is scanty source of electricity. Even the government admits that decentralized renewable energy solutions have to be deployed in large numbers in rural areas of mountain and plain region to deprive the last mile connectivity for un-electrified areas. They can turn to a bright new phase in their life if solar power solutions could be made available in all these deprived areas. For this it is very essential that people are aware of solar lighting gadgets. Present study was conducted to assess the awareness of hilly respondents regarding solar lighting gadgets and to see the association between educational level of the respondents and their awareness level about solar energy. For this Chi-square test was applied and the results were found to be significant at $\mathrm{p}<0.05$, indicating that educational level of respondents affect their awareness of solar energy and use of solar energy.

KEY WORDS: Solar energy, Solar lighting gadgets, Awareness level, Education level

- HOW TO CITE THIS PAPER : Joshi, Janki and Sharma, Promila (2019). Assessing the awareness of solar lighting gadgets among rural people of Uttarakhand. Asian J. Home Sci., 14 (2) : 293-296, DOI: 10.15740/HAS/AJHS/14.2/293-296. Copyright@ 2019: Hind Agri-Horticultural Society. 